\title{
Characteristics and Origin of Methane Adsorption Capacity of Marine, Transitional, and Lacustrine Shales in Sichuan Basin, China
}

\author{
Xianglu Tang $\mathbb{D}^{1},{ }^{1}$ Wei $W u,{ }^{2}$ Guanghai Zhong, ${ }^{2}$ Zhenxue Jiang $\mathbb{D},{ }^{1}$ Shijie He, ${ }^{1}$ Xiaoxue Liu, ${ }^{1}$ \\ Deyu Zhu, ${ }^{1}$ Zixin Xue, ${ }^{1}$ Yuru Zhou, ${ }^{1}$ and Jiajing Yang ${ }^{2}$ \\ ${ }^{1}$ State Key Laboratory of Petroleum Resources and Prospecting, China University of Petroleum, Beijing 102249, China \\ ${ }^{2}$ Shale Gas Research Institute, Southwest Oil \& Gas Field Company, PetroChina, Chengdu 610000, China \\ Correspondence should be addressed to Xianglu Tang; tangxl@cup.edu.cn and Zhenxue Jiang; zhenxue_jiang@sina.com
}

Received 9 November 2020; Revised 27 November 2020; Accepted 8 April 2021; Published 21 April 2021

Academic Editor: Reza Rezaee

Copyright (C) 2021 Xianglu Tang et al. This is an open access article distributed under the Creative Commons Attribution License, which permits unrestricted use, distribution, and reproduction in any medium, provided the original work is properly cited.

\begin{abstract}
Adsorbed gas is an important component of shale gas. The methane adsorption capacity of shale determines the composition of shale gas. In this study, the methane adsorption capacity of marine, transitional, and lacustrine shales in the Sichuan Basin was analyzed through its isothermal adsorption, mineral composition, water content, etc. The results show that the methane adsorption capacity of marine (Qiongzhusi Formation and Longmaxi Formation), transitional (Longtan Formation), and lacustrine (Xujiahe Formation and Ziliujing Formation) shales is significantly different. The Longtan Formation has the strongest methane adsorption capacity. This is primarily related to its high organic matter and organic matter type III content. The methane adsorption capacity of the lacustrine shale was the weakest. This is primarily related to the low thermal evolution degree and the high content of water-bearing clay minerals. Smectite has the highest methane adsorption capacity of the clay minerals, due to its crystal structure. The water content has a significant effect on methane adsorption largely because water molecules occupy the adsorption site. Additionally, the temperature and pressure in a specific range significantly affect methane adsorption capacity.
\end{abstract}

\section{Introduction}

As a clean fossil resource, natural gas has always been an important energy source for the world's industrial and economic development. As one of the important types of natural gas, shale gas is an abundant resource, and the shale revolution has changed the global oil and gas supply [1-3]. North America and China are the primary regions of commercial shale gas development. In 2019, the production of shale gas in the United States reached $7151 \times$ $10^{8} \mathrm{~m}^{3}$, accounting for $62.0 \%$ of the total gas production, the highest production in North America. China's shale gas production reached $154 \times 10^{8} \mathrm{~m}^{3}$ in 2019 . The Sichuan Basin is an important petroliferous basin where China's shale gas exploration and development has made the most rapid progress and the earliest commercial development $[4,5]$.
Shale gas is divided into adsorbed gas, free gas, and dissolved gas. Adsorbed gas and free gas are the primary forms of shale gas [6]. Adsorbed gas is a popular focus of shale gas research, largely because the control factors of adsorbed gas are complex. According to the different adsorption forces, adsorption can be divided into two types: chemical adsorption and physical adsorption. Physical adsorption is VDW (Van der Waals' force) adsorption, which is produced by the interaction force between the adsorbate and adsorbed molecules. It includes the dispersion force, electrostatic force, and induction force. Physical adsorption is the principal type of adsorption for shale gas [7].

Adsorbed gas and free gas codetermine the scale of shale gas accumulation, and the dominant position of the two changes with the accumulation conditions, shale, gas molecules, etc. [8]. The adsorption starts quickly, and the adsorbed gas molecules are then easily desorbed from the 


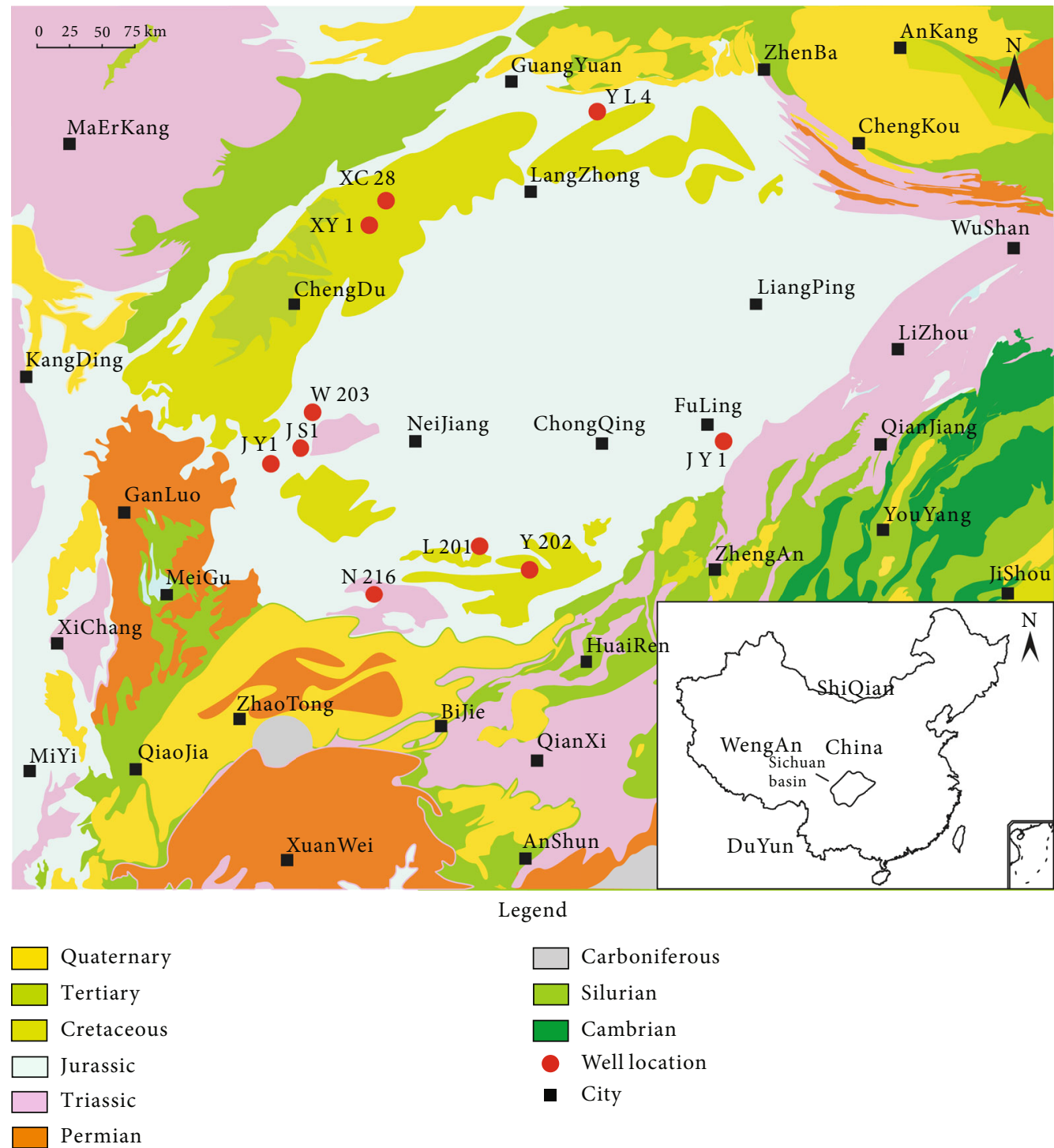

Figure 1: Stratum characteristics and sampling locations in the Sichuan Basin. Shales are primarily developed in the Cambrian Qiongzhusi Formation, the Ordovician Wufeng Formation, the Silurian Longmaxi Formation, the Permian Longtan Formation, the Triassic Xujiahe Formation, and the Jurassic Ziliujing Formation. A total of 10 wells and 152 samples were selected for analysis.

surface of the shale particles and enter the dissolved and free phases. When the adsorption and desorption speeds are equal, the adsorption reaches a dynamic equilibrium. With the massive generation of natural gas, the internal pressure of the shale rises, causing gaps and discharge, and free gas enters the sandstone to form conventional gas reservoirs [9].

Unlike conventional gas reservoirs, shale has a high content of adsorbed gas $[10,11]$. Therefore, it is necessary to conduct a detailed study on the adsorption capacity of shale to determine the various factors that affect its adsorption capacity. The adsorption capacity of shale is primarily related to the organic carbon content, mineral composition, reservoir temperature, formation pressure, shale water content, gas component, shale density, and pore structure [12-16]. When the formation pressure is low, gas adsorption requires a higher binding energy. When the pressure increases, the required binding energy decreases, and the rate of increase of the gas adsorption capacity declines [17]. Reservoir temperature has a great influence on methane adsorption capacity. The higher the temperature, the lower the methane adsorption capacity. The shale gas in the Upper Jurassic Gordondale Formation in northeastern Canada has a methane adsorption capacity of $0.05-2.00 \mathrm{~cm}^{3} / \mathrm{g}$ at $60 \mathrm{MPa}$ and $30^{\circ} \mathrm{C}$ [18]. Additionally, there is a positive relationship between organic carbon content and methane adsorption capacity [19]. While both clay minerals and kerogen adsorb gas, the adsorption capacity of kerogen is stronger than that of clay. Although the adsorption capacity of clay is relatively weak, it still contains a large amount of gas and cannot be ignored [20,21]. Only when the water content is large (higher than 4\%) is the gas adsorption capacity of shale significantly reduced, and the gas adsorption capacity of samples saturated with water was $40 \%$ lower than that of dry samples [18]. 


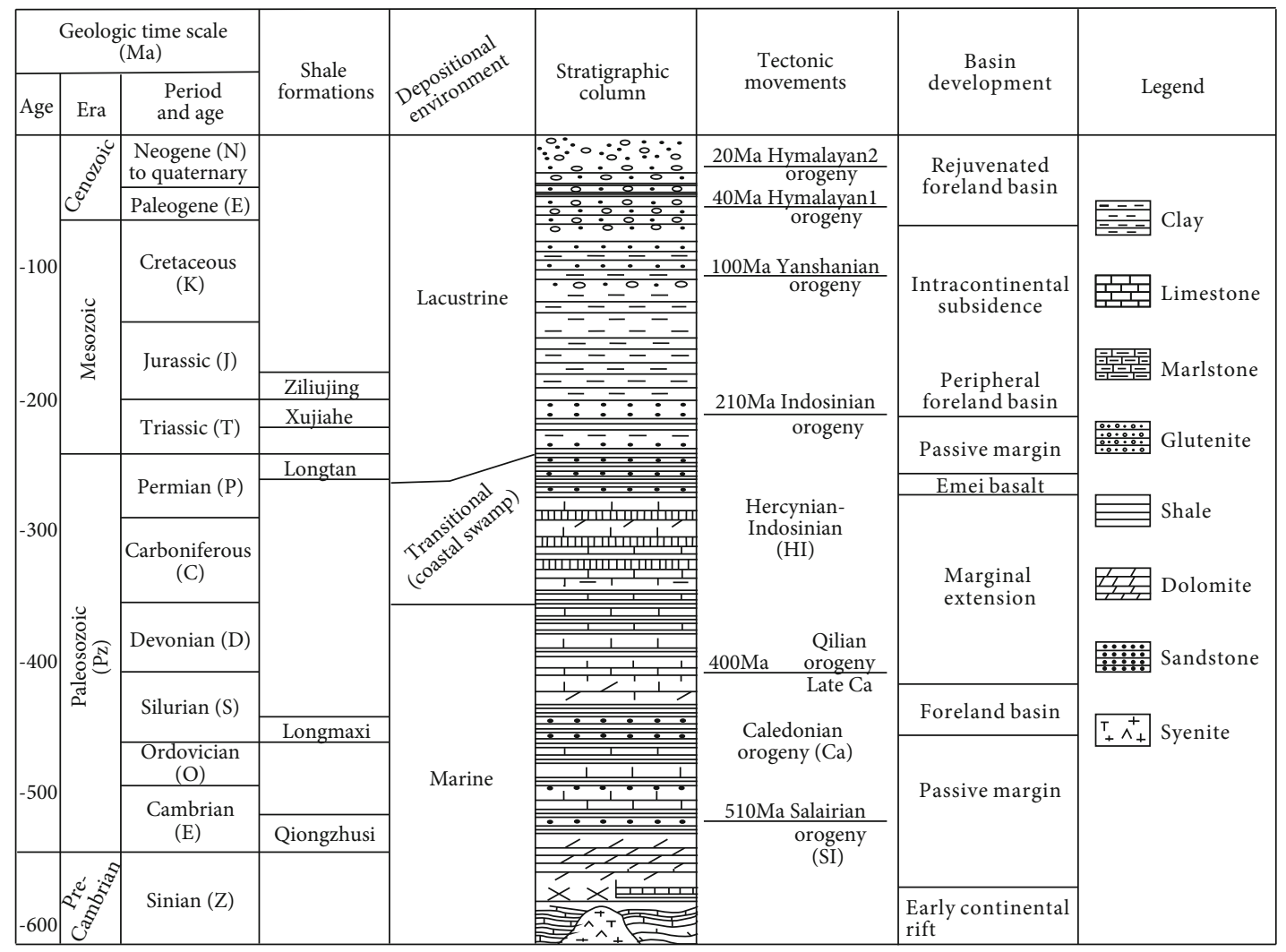

Figure 2: Structural evolution and Stratigraphic histogram of Sichuan Basin. The Qiongzhusi Formation, Wufeng Formation, Longmaxi Formation, Longtan Formation, Xujiahe Formation, and Ziliujing Formation shales are primarily developed in the Sichuan Basin.

There are multiple sets of shale formations in the Sichuan Basin, China. The occurrence status of marine shale, transitional shale, and lacustrine shale gas is not clear, and the influence of shale reservoir parameters and the external environment on shale gas adsorption capacity has not been determined. The microscopic mechanisms of shale gas adsorption have not been clarified, which hinders the understanding of shale gas formation. Thus, we selected typical marine shale (Qiongzhusi Formation with 27 samples, Longmaxi Formation with 54 samples), transitional shale (Longtan Formation with 37 samples), and lacustrine shale (Xujiahe Formation with 19 samples, Ziliujing Formation with 15 samples) in the Sichuan Basin for methane adsorption capacity analysis (Figure 1). In order to guide shale gas exploration and development, the primary controlling factors of methane adsorption capacity were determined through the analysis of shale composition, water content, temperature, and pressure.

\section{Geological Setting}

The Sichuan Basin is part of the Upper Yangtze Plate and is a petroliferous basin surrounded by complex fold belts. There are six sets of potential shale gas layers in the Sichuan Basin. From old to new, they are the Lower Cambrian Qiongzhusi Formation Shale, Upper Ordovician Wufeng Formation Shale, Lower Silurian Longmaxi Formation Shale, Permian Longtan Formation Shale, Triassic Xujiahe Formation Shale, and Lower Jurassic Ziliujing Formation Shale. Among them, the Lower Cambrian, Upper Ordovician, and Lower Silurian are marine shale, the Permian is transitional shale, and the Upper Triassic and Lower Jurassic are lacustrine shales. These shales have reached the standard of effective gas sources, especially the marine shale, which has many layers and a wide distribution, and have entered a high and overmature stage, with a higher gas generation rate [22-24].

The evolution of the Sichuan Basin goes through five stages, namely, the Presinian basement formation stage, the Sinian-Middle Triassic kratogen basin stage, the Late Triassic foreland basin stage, the Early Jurassic-Late Cretaceous depression basin stage, and the Cenozoic tectonic basin stage (Figure 2). The Sinian-Middle Triassic is dominated by platform-type marine carbonate rocks, interbedded with transitional facies argillaceous sediments, with a thickness of 4000-6000 m. After the Indosinian period, seawater exited the area resulting in a terrestrial environment [25]. The basin began to enter the foreland and depression stages. The Upper Triassic and above strata were dominated by clastic rocks with a thickness of $2000-6000 \mathrm{~m}$.

The Qiongzhusi and Longmaxi Formation shales are a set of deep-water shelf black carbonaceous shales [26]. The Longtan Formation transitional shale is thick and has many layers. The lithology is a set of shale strata with black shale as the foundation and frequent interbeds of siltstone, limestone, and coal seams. The sedimentary facies of the Triassic Xujiahe Formation and the Lower Jurassic Ziliujing Formation are large-scale black shale strata of lacustrine deposits, dominated by shore-shallow lake deposits, with a shale thickness of $40-120 \mathrm{~m}$, and the distribution is stable. The primary 
TABLE 1: Characteristics of shale in different formation in the Sichuan Basin.

\begin{tabular}{|c|c|c|c|c|c|c|c|c|c|}
\hline $\begin{array}{l}\text { Deposition } \\
\text { type }\end{array}$ & Formation & $\begin{array}{l}\text { Number of } \\
\text { samples }\end{array}$ & Organic matter type & $\begin{array}{c}\text { TOC } \\
(\%)\end{array}$ & $\begin{array}{l}\text { Ro } \\
(\%)\end{array}$ & $\begin{array}{l}\text { Quartz } \\
(\%)\end{array}$ & $\begin{array}{l}\text { Feldspar } \\
\quad(\%)\end{array}$ & $\begin{array}{l}\text { Carbonate } \\
\text { minerals (\%) }\end{array}$ & $\begin{array}{c}\text { Clay } \\
\text { minerals } \\
(\%)\end{array}$ \\
\hline \multirow{2}{*}{$\begin{array}{l}\text { Lacustrine } \\
\text { shale }\end{array}$} & $\begin{array}{l}\text { Ziliujing } \\
\text { Formation }\end{array}$ & 13 & $\begin{array}{l}\text { Mainly type } \mathrm{II}_{1} \text { and } \mathrm{II}_{2} \text {, } \\
\text { partly type } \mathrm{III}\end{array}$ & $\begin{array}{c}0.7- \\
3.9 \\
2.1\end{array}$ & $\begin{array}{c}1.6- \\
1.8 \\
1.7\end{array}$ & $\begin{array}{c}15.3- \\
78.8 \\
25.3\end{array}$ & $\begin{array}{c}4.2-23.4 \\
8.2\end{array}$ & $\begin{array}{c}1.3-38.6 \\
22.4\end{array}$ & $\begin{array}{c}21.6-78.1 \\
44.1\end{array}$ \\
\hline & $\begin{array}{l}\text { Xujiahe } \\
\text { Formation }\end{array}$ & 17 & $\begin{array}{l}\text { Mainly type } \mathrm{II}_{1} \text { and } \mathrm{II}_{2} \text {, } \\
\text { partly type III }\end{array}$ & $\begin{array}{c}0.7- \\
5.9 \\
2.2\end{array}$ & $\begin{array}{c}1.2- \\
1.5 \\
1.3\end{array}$ & $\begin{array}{c}12.1- \\
53.0 \\
35.9\end{array}$ & $\begin{array}{c}0.4-6.3 \\
3.9\end{array}$ & $\begin{array}{c}0.6-67.0 \\
14.2\end{array}$ & $\begin{array}{c}15.1-57.3 \\
46.0\end{array}$ \\
\hline $\begin{array}{l}\text { Transitional } \\
\text { shale }\end{array}$ & $\begin{array}{l}\text { Longtan } \\
\text { Formation }\end{array}$ & 35 & $\begin{array}{l}\text { Mainly type III, followed } \\
\text { by } \mathrm{II}_{2}\end{array}$ & $\begin{array}{c}0.5- \\
13.0 \\
4.8\end{array}$ & $\begin{array}{l}1.3- \\
2.0 \\
1.6\end{array}$ & $\begin{array}{c}10.9- \\
71.7 \\
28.9\end{array}$ & $\begin{array}{c}2.0-24.8 \\
11.6\end{array}$ & $\begin{array}{c}2.3-86.6 \\
21.3\end{array}$ & $\begin{array}{c}5.1-77.8 \\
38.2\end{array}$ \\
\hline \multirow{2}{*}{ Marine shale } & $\begin{array}{l}\text { Longmaxi } \\
\text { Formation }\end{array}$ & 52 & Mainly type I, part $\mathrm{II}_{1}$ & $\begin{array}{c}0.4- \\
5.6 \\
1.8\end{array}$ & $\begin{array}{c}2.1- \\
2.9 \\
2.4\end{array}$ & $\begin{array}{c}28.7- \\
76.3 \\
42.2\end{array}$ & $\begin{array}{c}4.2-19.3 \\
9.8\end{array}$ & $\begin{array}{c}8.3-33.3 \\
16.7\end{array}$ & $\begin{array}{c}26.7-53.0 \\
31.3\end{array}$ \\
\hline & $\begin{array}{l}\text { Qiongzhusi } \\
\text { Formation }\end{array}$ & 25 & Mainly $\mathrm{I}_{1} \mathrm{II}_{1}$ type & $\begin{array}{c}0.9- \\
9.9 \\
4.5\end{array}$ & $\begin{array}{c}3.2- \\
3.6 \\
3.3\end{array}$ & $\begin{array}{c}26.2- \\
70.6 \\
44.1\end{array}$ & $\begin{array}{c}3.5-26.1 \\
10.3\end{array}$ & $\begin{array}{c}2.5-16.5 \\
12.1\end{array}$ & $\begin{array}{c}23.8-54.5 \\
33.6\end{array}$ \\
\hline
\end{tabular}

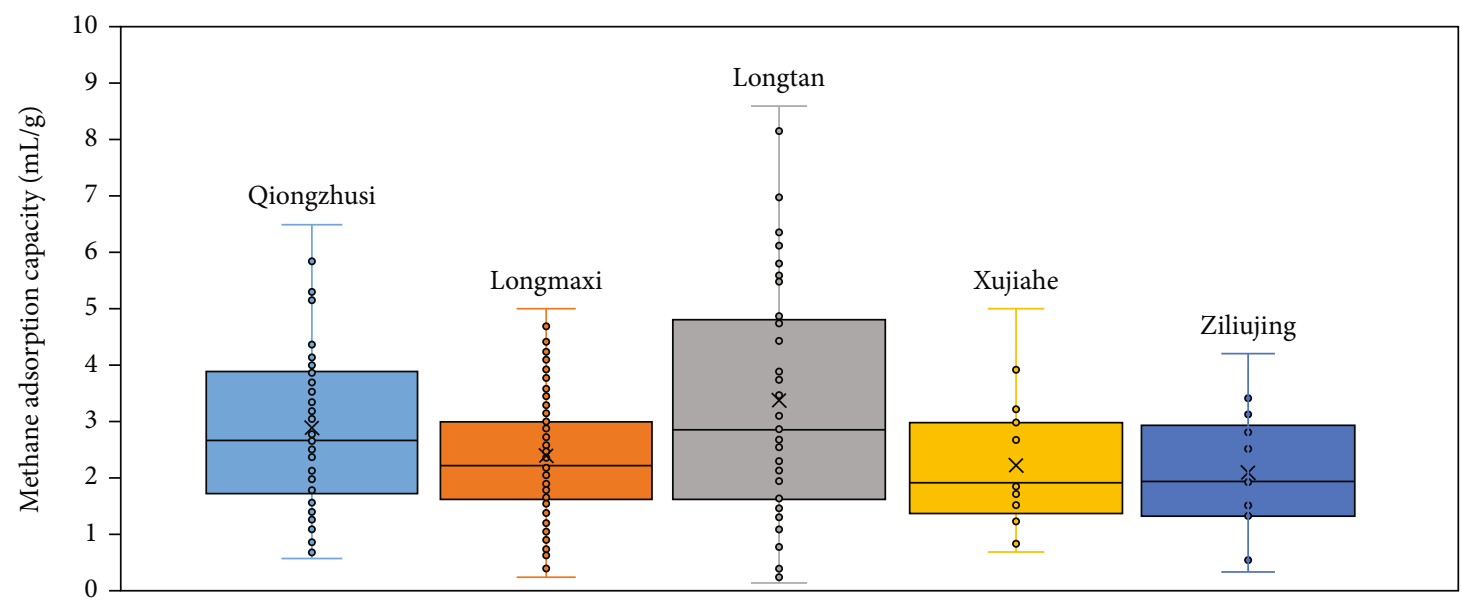

FIGURE 3: Methane adsorption capacity of different types of shale. All 5 sets of shales have high methane adsorption capacity, among which the Longtan Formation Shale has the strongest methane adsorption capacity, followed by the Qiongzhusi Formation and the Longmaxi Formation.

lithology is thin gray-black shale, siltstone, and thin green marl. Climbing ripple bedding, wavy sand bedding, and horizontal bedding are common sedimentary structures.

\section{Experimental Methods}

3.1. Methane Isothermal Adsorption. The detection equipment used for methane isotherm adsorption is a ZJ466 HP Static III magnetic levitation balance high-pressure gas adsorption isotherm instrument. The resolution of the magnetic levitation balance is $0.01 \mathrm{mg}$, the environmental condition is $23.5^{\circ} \mathrm{C}$, and the maximum test pressure is $30 \mathrm{MPa}$. First, sample particles of $0.18-0.43 \mathrm{~mm}$ were placed in a sealed chamber, and the methane adsorption was tested under different pressures at a constant temperature. The weight change recorded by the magnetic levitation balance was used to obtain the mass of methane gas, calculate the shale adsorption characteristic parameters according to the Langmuir theoretical model, and draw the adsorption isotherm curve. Five sets of shales with 152 samples were tested. Additionally, each component of shale, including organic matter, quartz, feldspar, carbonate minerals, smectite, illite/smectite, illite, and chlorite, was tested for methane adsorption capacity.

3.2. Organic Matter Content, Type, and Maturity. Organic matter content was tested using a C-S determining apparatus. Dilute hydrochloric acid was used to remove the inorganic carbon in the sample, and then it was burned in hightemperature oxygen to convert the total organic carbon into carbon dioxide. The organic carbon was checked by an infrared detector, and the total organic carbon content was determined. The sample was powdered with a particle size of less than $0.2 \mathrm{~mm}$. The organic matter type was tested using a biological microscope with transmitted light and reflected fluorescence functions to identify the microscopic components of kerogen in shale and calculate the percentage of each 


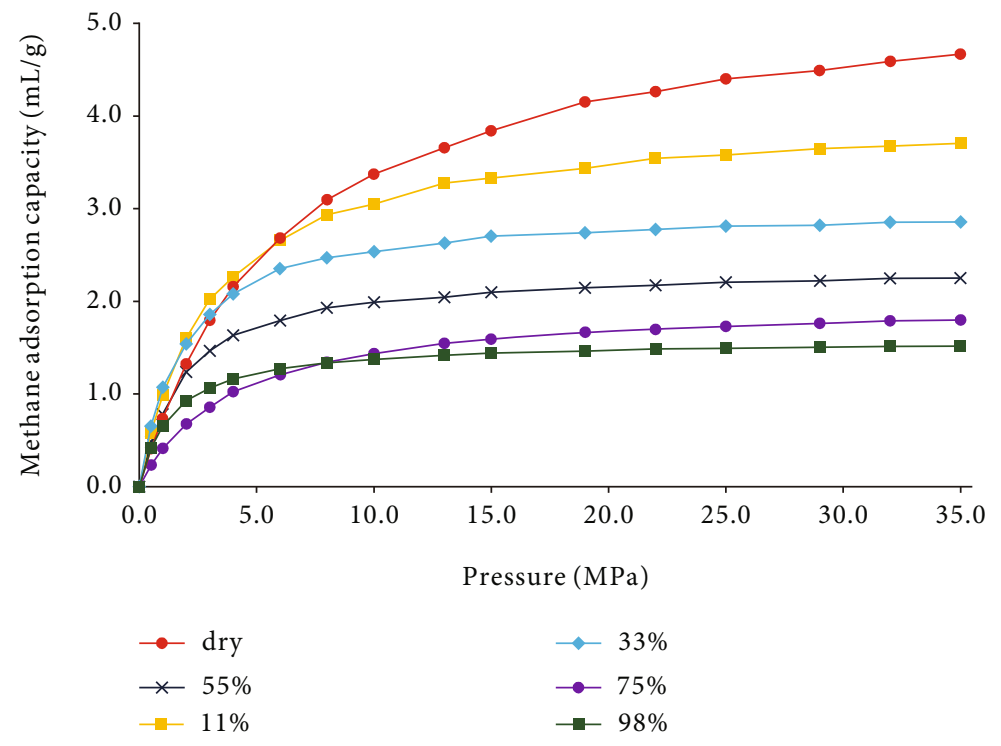

FIGURE 4: Methane adsorption isotherms of shale under different humidity conditions. As the humidity increases, the methane adsorption capacity of the sample decreases.

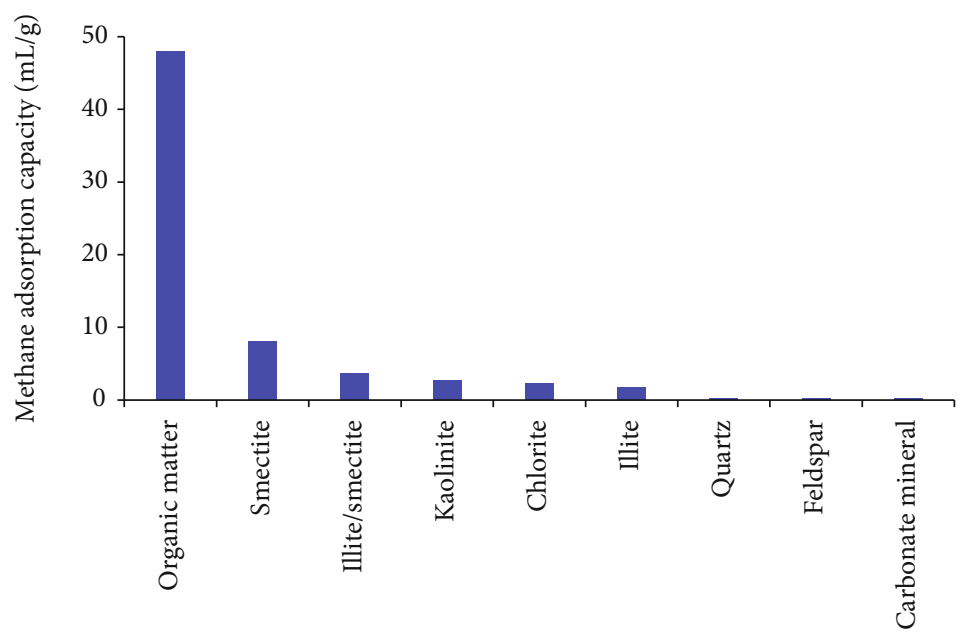

FIGURE 5: Methane adsorption capacity of different components. Organic matter has a significantly higher methane adsorption capacity than other components. Brittle minerals have the lowest adsorption capacity.

microscopic component according to their different weighting coefficients and calculate the type index and divide the kerogen into four types: $\mathrm{I}_{1} \mathrm{II}_{1}, \mathrm{II}_{2}$, and III. The maturity of organic matter was obtained by the vitrinite reflectance method. Vitrinite reflectance refers to the percentage of the intensity of the reflected light from the polished surface of the vitrinite at a wavelength of $546 \mathrm{~nm} \pm 5 \mathrm{~nm}$. It is obtained through the photoelectric effect principle by converting the reflected light intensity into current intensity through a photomultiplier tube and comparing it with the current intensity generated by a standard sample with known reflectivity under the same conditions.

3.3. Mineral Composition. The mineral composition was obtained using an X-ray diffractometer. Each mineral crystal has a specific X-ray diffraction pattern. The content of a certain mineral in the sample is proportional to the intensity of its diffraction peak. The test voltage was $40 \mathrm{kV}$, the current was $40 \mathrm{~mA}$, the target was $\mathrm{Cu}$, and the measuring angle range was $5^{\circ}-70^{\circ}$. First, the sample was dried at $60^{\circ} \mathrm{C}$, and then the sample was crushed to less than $40 \mu \mathrm{m}$. The powder was placed on a frosted glass plate, pressed to shape, and tested.

3.4. Humidity. Shales with different water contents were obtained through a balanced water experiment and were used to analyze the influence of water content on methane adsorption capacity. During the equilibrium water experiment, the moisture content in the sample principally depends on the humidity of the environment. The higher the relative humidity, the higher the water content in the environment, and the higher the water content adsorbed 


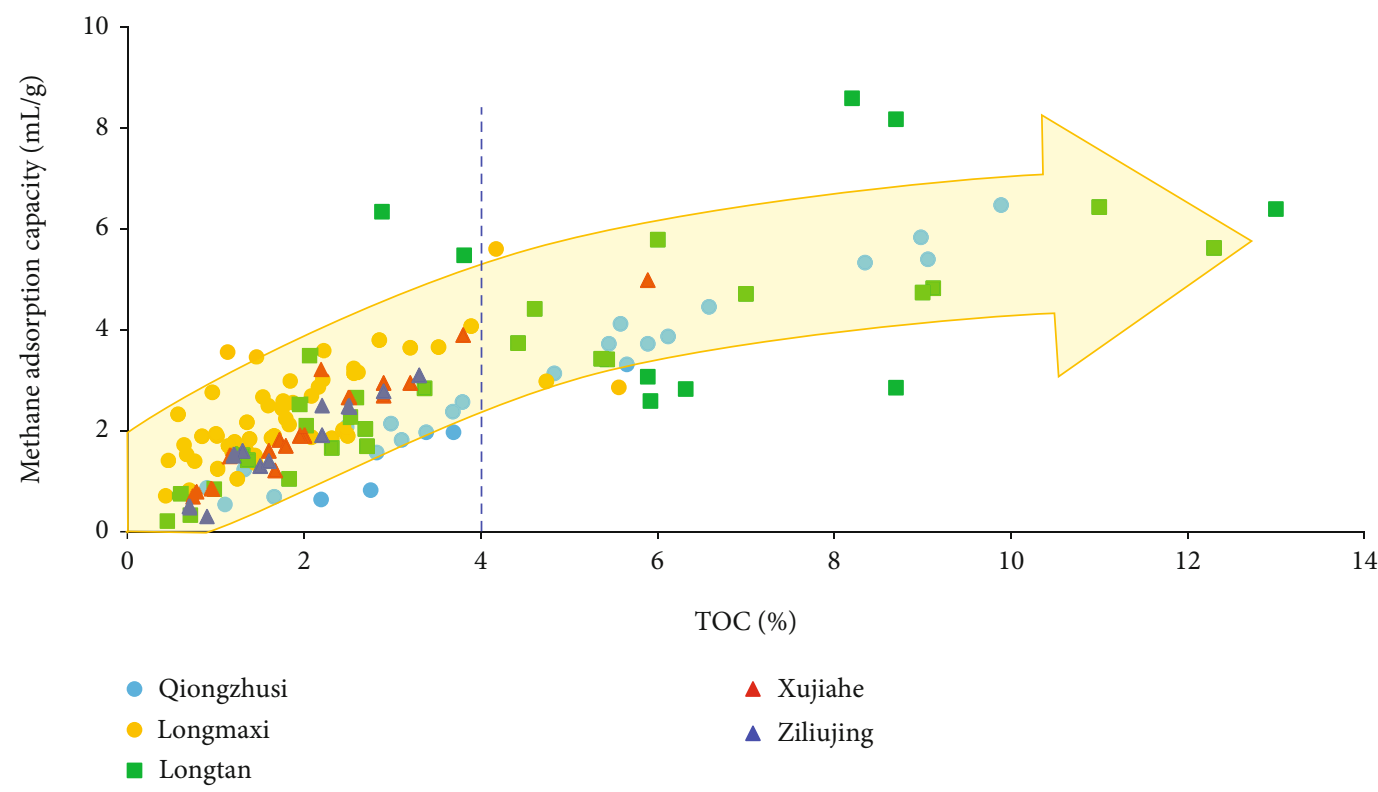

FIGURE 6: Relationship between methane adsorption capacity and TOC of different types of shale. With the increase of TOC content, methane adsorption capacity increases gradually. After TOC $>0.4 \%$, the increase range decreases.

in the sample pores, the higher the water saturation. Conversely, if the relative humidity of the environment is low, the moisture in the sample will also evaporate. Therefore, there is a one-to-one correspondence between the humidity in the environment and the moisture content in the sample. In order to get samples with different degrees of saturation, different solutes were used. In this experiment, five solutes, namely, zinc chloride, magnesium chloride, sodium bromide, sodium chloride, and magnesium sulfate, were selected, corresponding to samples with a humidity of $11 \%, 33 \%, 55 \%, 75 \%$, and $98 \%$, respectively. The temperature of the experiment was $30^{\circ} \mathrm{C}$. Shale samples as well as organic matter and single minerals such as smectite, illite, chlorite, and kaolinite in the shale were tested.

\section{Results}

4.1. Characteristics of Shale. The geochemical characteristics of shale in different strata in the Sichuan Basin are quite different (Table 1). The total organic carbon (TOC) varies widely, ranging from $0.4 \%$ to $13.0 \%$. Generally, the Qiongzhusi and Longtan formations have higher TOC values, followed by the Longmaxi Formation, Xujiahe Formation, and Ziliujing Formation. The maturity, Ro, is $1.2 \%-3.6 \%$, and the order of values is usually Qiongzhusi Formation $>$ Longmaxi Formation $>$ Longtan Formation,

Xujiahe Formation, and Ziliujing Formation. There are obvious differences in the types of organic matter. The marine shales were primarily type $\mathrm{I}$ and $\mathrm{II}_{1}$, the transitional shales were type III, and the lacustrine shales were type $\mathrm{II}_{1}$ and $\mathrm{II}_{2}$. The marine shale is dominated by dark shale, and its minerals are primarily quartz, clay, carbonate minerals, and other types of minerals. The clay mineral content in lacustrine shale is higher, with an average content of over $40 \%$.

\subsection{Methane Adsorption Capacity}

4.2.1. Methane Adsorption Capacity of Shale under the Same Humidity Conditions. The methane adsorption capacity of the Qiongzhusi Formation is in the range of $1-4 \mathrm{~mL} / \mathrm{g}$, with an average of $2.87 \mathrm{~mL} / \mathrm{g}$, indicating a high adsorption capacity (Figure 3). The methane adsorption capacity of the Longmaxi Formation is in the range of $1-4 \mathrm{~mL} / \mathrm{g}$, with an average of $2.38 \mathrm{~mL} / \mathrm{g}$, also indicating a strong adsorption capacity. The methane adsorption capacity of the Longtan Formation is widely distributed, the peak value ranges from $1-4 \mathrm{~mL} / \mathrm{g}$, and there are many samples greater than $4 \mathrm{~mL} / \mathrm{g}$, with an average of $3.36 \mathrm{~mL} / \mathrm{g}$, the strongest adsorption capacity. The range of the methane adsorption capacity of Xujiahe Formation shale is $1-3 \mathrm{~mL} / \mathrm{g}$, with an average of $2.19 \mathrm{~mL} / \mathrm{g}$, indicating that the adsorption capacity of the Xujiahe Formation shale is relatively weak. The range of methane adsorption capacity of the Ziliujing group is $1-3 \mathrm{~mL} / \mathrm{g}$, with an average of $2.07 \mathrm{~mL} / \mathrm{g}$, showing relatively weak adsorption capacity. A comprehensive comparison shows that the Longtan Formation transitional shale has the strongest adsorption capacity, followed by the Qiongzhusi Formation and Longmaxi Formation marine shales, and the Xujiahe Formation and Ziliujing Formation lacustrine shale have the weakest adsorption capacity.

4.2.2. Methane Adsorption Capacity of Shale under Different Humidity Conditions. Experiments on the methane adsorption capacity of shale under different levels of humidity, from absolute drying to $98 \%$ humidity control, showed the increase in water content reduced the methane adsorption 


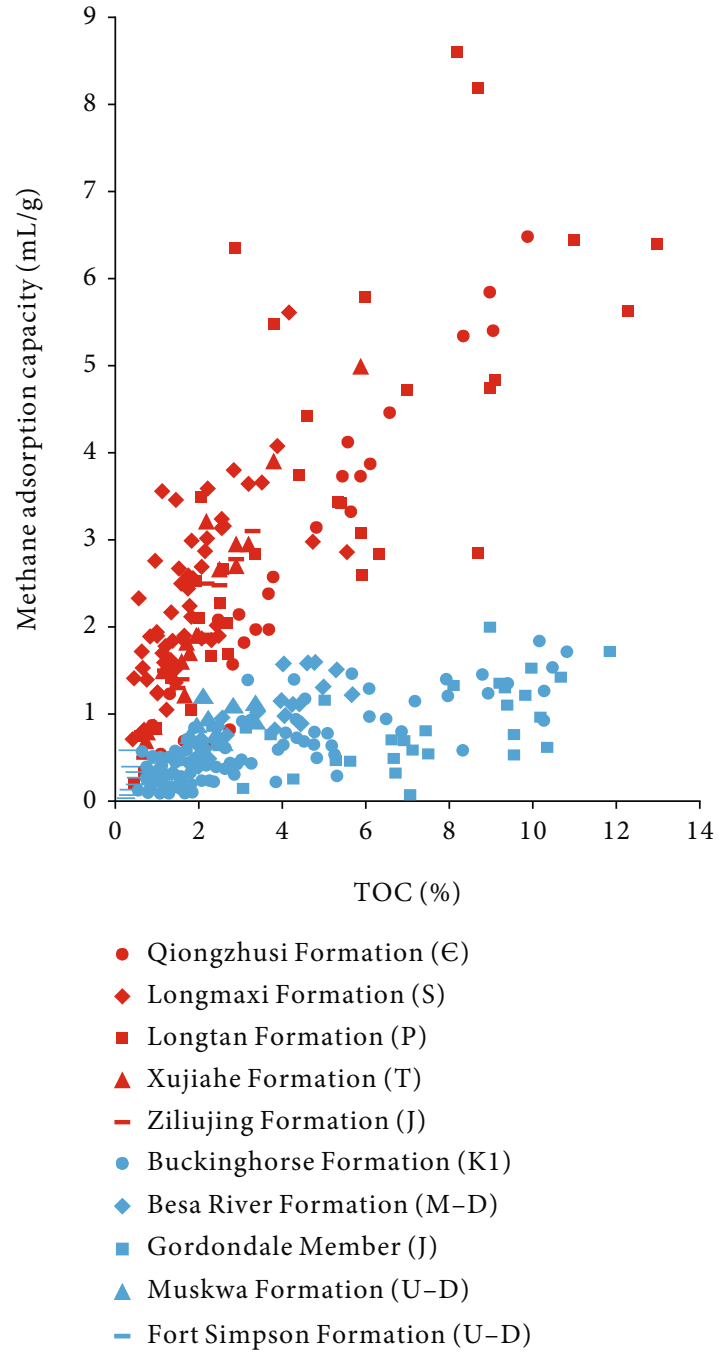

FIGURE 7: Comparison of shale adsorption capacities of Sichuan Basin and North America. The adsorption capacity of 5 sets of shales in Sichuan Basin is higher than that in North America. (Part of data is from Reference [12, 14]). Red points represented shale adsorption capacities of Sichuan Basin, and blue points represented that of North America. Besides, the era of different Formation was labelled in following parentheses.

capacity of shale (Figure 4). When the humidity increases to $98 \%$, the shale adsorption capacity drops from $4.90 \mathrm{~mL} / \mathrm{g}$ to $1.35 \mathrm{~mL} / \mathrm{g}$, and the adsorption capacity of the dry sample drops to $28 \%$.

\subsubsection{Methane Adsorption Capacity of Different Shale} Components. Testing the methane adsorption capacity of a single component of shale shows that the methane adsorption capacity of different components varies greatly. The adsorption capacity of organic matter was the strongest, reaching $48 \mathrm{~mL} / \mathrm{g}$. Among the clay minerals, smectite has the strongest adsorption capacity, followed by illite/smectite, kaolinite, chlorite, and illite. Brittle minerals such as quartz and feldspar have the weakest methane adsorption capacity, with an average of only $0.2 \mathrm{~mL} / \mathrm{g}$ (Figure 5 ). Therefore, the difference in methane adsorption capacity of different com- ponents jointly determines the methane adsorption capacity of shale.

\section{Discussion}

\subsection{Shale Components}

5.1.1. Organic Matter Content. The methane adsorption capacity of the five sets of shales shows a significant positive correlation (nonlinear) with organic matter content, but the correlation coefficients of the five sets of shales are different (Figure 6). When TOC $<4 \%$, the adsorption capacity was positively correlated with organic matter. When TOC $>4 \%$, the adsorption capacity did not increase significantly with the increase in organic matter, indicating that the adsorption capacity had a certain upper limit. Therefore, the organic carbon content is an important factor in controlling shale gas adsorption. The increase in organic carbon content will improve the methane adsorption capacity of shale for two primary reasons: first, the shale with a higher organic carbon value has a greater gas potential, so it has a higher gas content per unit volume of shale. Second, owing to the characteristics of kerogen, micropores can be developed, the surface is oilwet, and the adsorption capacity of gaseous hydrocarbons is relatively strong. At the same time, the dissolution of gaseous hydrocarbons in amorphous and structural-matrix bituminites has a nonnegligible contribution [27]. In the five sets of shales, the Qiongzhusi and Longtan formations tend to have higher TOC levels to match their strong shale gas adsorption capacity.

The Sichuan Basin shale has similar adsorption characteristics to the North American shale, and its organic carbon content is positively correlated with methane adsorption capacity $[28,29]$. However, the shale in Sichuan shows a stronger methane adsorption capacity. The methane adsorption capacity of shales in Sichuan and shales in North American can be up to three times worse. The Sichuan Basin shale TOC is about 3 times as high as that of the North American shale, which is more favorable for gas adsorption (Figure 7).

This may be related to the type and maturity of organic matter. The organic matter of the Longtan Formation, Xujiahe Formation, and Ziliujing Formation shales in the Sichuan Basin are primarily composed of types II and III, which have strong adsorption capacity. This is because the III kerogen type, relative to the I and II kerogen, has a high content of aromatic hydrocarbons and enhances the adsorption capacity of shale [30]. Additionally, the vitrinite relative to the other ingredients has a stronger adsorption ability, and III kerogen contains a higher concentration of vitrinite, thus, enhancing the adsorption ability of the shale. The Longmaxi and Qiongzhusi shales, of the same organic type as North American shales, are highly thermally evolved with more developed organic pores, leading to increased adsorption capacity $[4,28,31]$.

5.1.2. Organic Matter Maturity. The relationship between the adsorption capacity and maturity of the five shale formations in the Sichuan Basin shows that when $R_{o}<3 \%$, the methane adsorption capacity per TOC of each formation gradually 


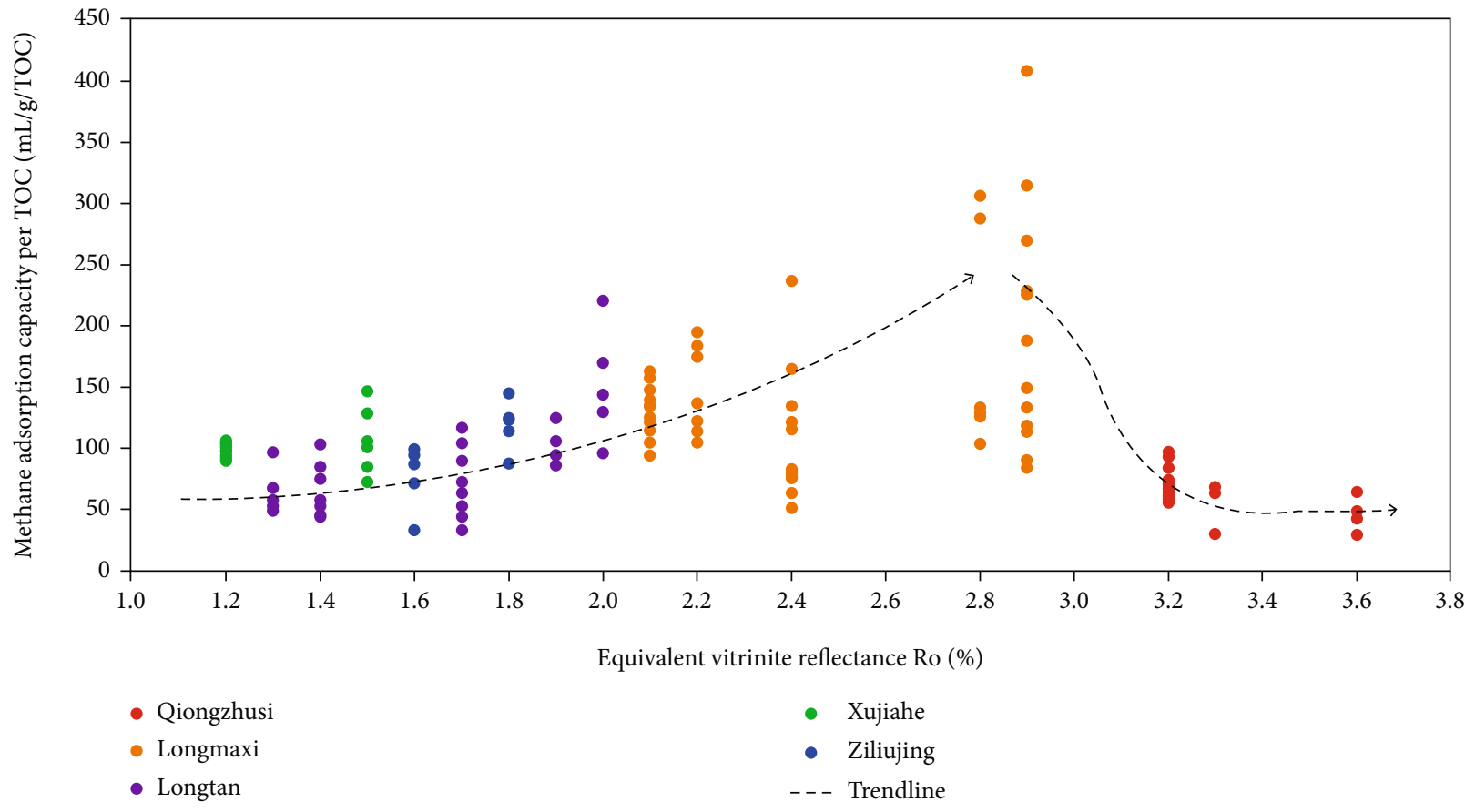

FIGURE 8: Relationship between methane adsorption capacity per TOC and maturity of different types of shale. With the increase of maturity, the adsorption capacity first increased and then decreased.

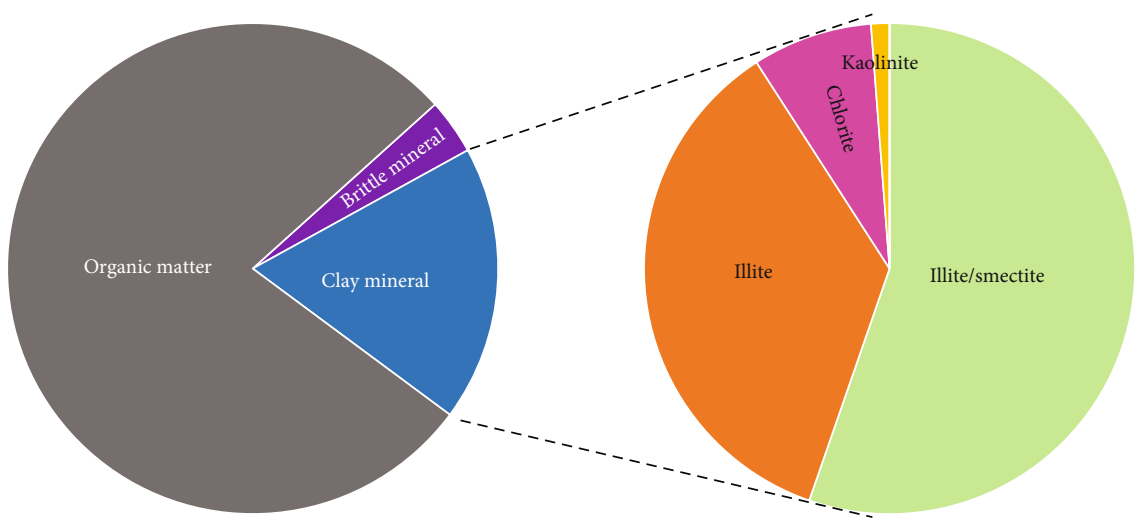

FIGURE 9: Theoretical calculation of adsorbed gas proportion. The adsorption capacity of organic matter was the highest, followed by clay minerals, and the adsorption capacity of brittle minerals was the lowest.

increases with an increase in maturity (Figure 8). The Qiongzhusi Formation $R_{o}$ is greater than 3\% with relatively high maturity and showed a gradual decrease in methane adsorption capacity per TOC as maturity increased. The adsorption capacity per TOC of shale in the Longmaxi Formation was significantly higher, which may be related to its appropriate thermal evolution degree $\left(2 \%<R_{o}<3 \%\right)$.

The effect of maturity on shale adsorption capacity is primarily influenced by the development of organic matter pores. With the increase in maturity, the methane adsorption capacity of shale increases [32]. Under similar conditions of organic matter content and type, the methane adsorption capacity of overmature shale was higher than that of the high mature shale. The reason for this is that the increase in maturity creates more organic pores in shale, thus, producing more micropores and mesopores and increasing the methane adsorption capacity of shale. When the maturity is too high, the adsorption capacity and maturity will be negatively correlated, and the methane adsorption capacity decreases.

5.1.3. Clay Minerals. Using the methane adsorption capacity of organic matter and minerals and the composition content of shale, the contribution of each shale component to the methane adsorption capacity of shale as a whole can be calculated. According to theoretical calculations, 3.0\% TOC, $26.6 \%$ clay minerals, and $67.4 \%$ brittle minerals represent a typical composition of the shales in the Longmaxi Formation [33]. In each gram of shale, organic matter can absorb $2.9 \mathrm{~mL}$ methane, and clay minerals can absorb $0.7 \mathrm{~mL}$ methane, accounting for $19.4 \%$ of the total amount of adsorbed gas 


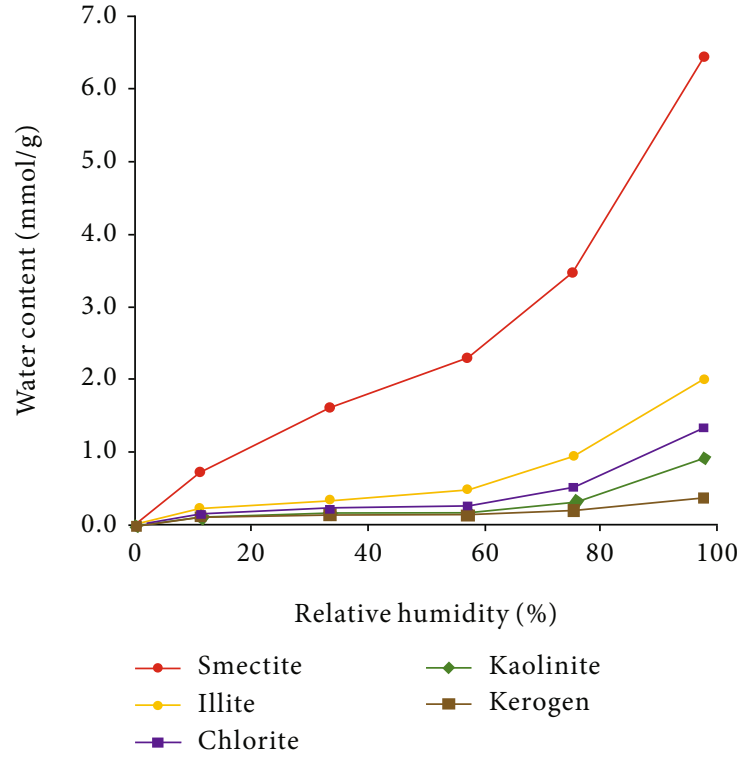

(a)

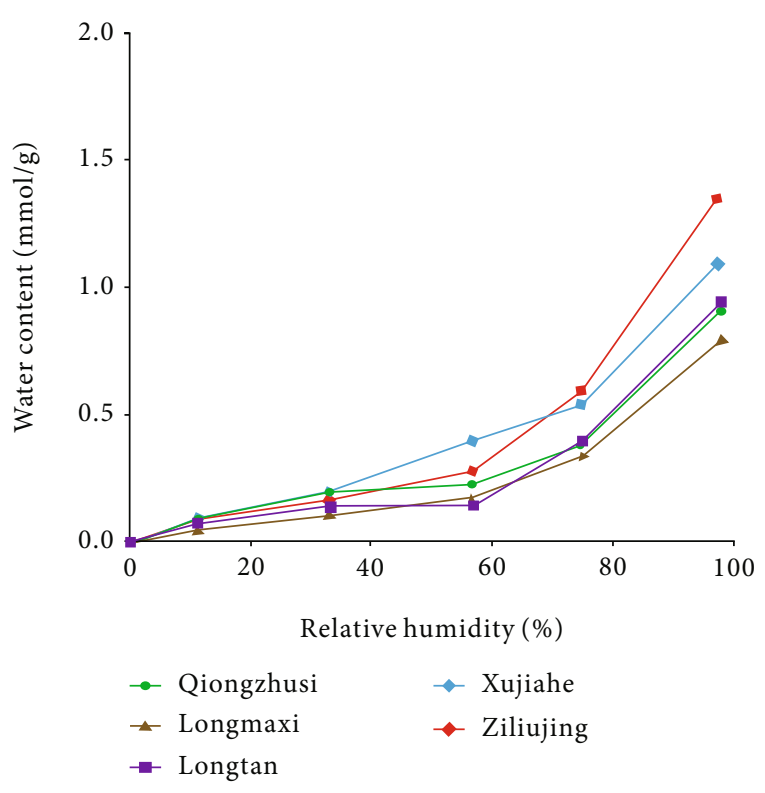

(b)

Figure 10: Water absorption capacity of different clay minerals and different shales. (a) The relationship between the water content of clay minerals and the relative humidity. (b) The relationship between water content of shale and relative humidity.

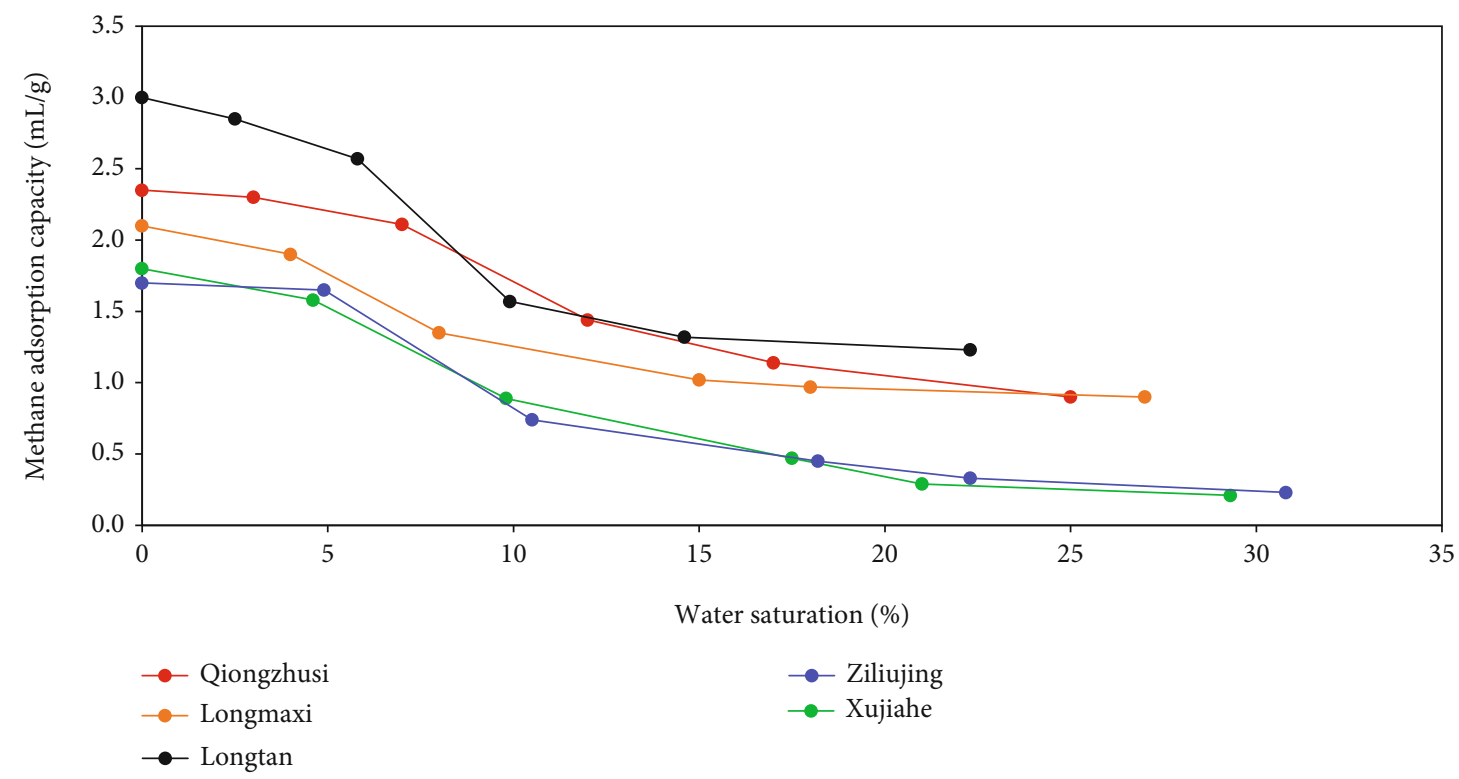

FIGURE 11: The influence of water saturation of different types of shale on the methane adsorption capacity.

(Figure 9). Therefore, the methane adsorption capacity of clay minerals cannot be ignored. The clay minerals in shale primarily consist of illite, smectite, illite/smectite, kaolinite, and chlorite. Because the clay mineral content, chemical characteristics, and pore structure are different, they contributed differently to the absorption ability of shale. The Mississippi shale shows that illite has the largest specific surface area, followed by smectite, and kaolinite is the smallest [34]. Under dry conditions, the adsorption capacity of clay minerals is consistent with the order of the specific surface area, and the order of clay minerals gas adsorption capacity is smectite $>$ kaolinite $>$ illite. The methane isothermal adsorp- tion experiment was performed on dried samples of each single mineral at $65^{\circ} \mathrm{C}$, and the adsorption capacity of clay minerals was obtained in the order of smectite $>$ illite/ smectite $>$ kaolinite $>$ chlorite $>$ illite [35].

5.2. Water Content. Hydrophilicity is an important characteristic of clay minerals [36]. Clay minerals have different lattice structures and different water-absorbing swelling capabilities. Smectite has the strongest water swelling properties and is stronger than both illite and kaolinite. This is because the traction between the oxygen layers in the smectite crystal layer is very small, and the water molecules easily 


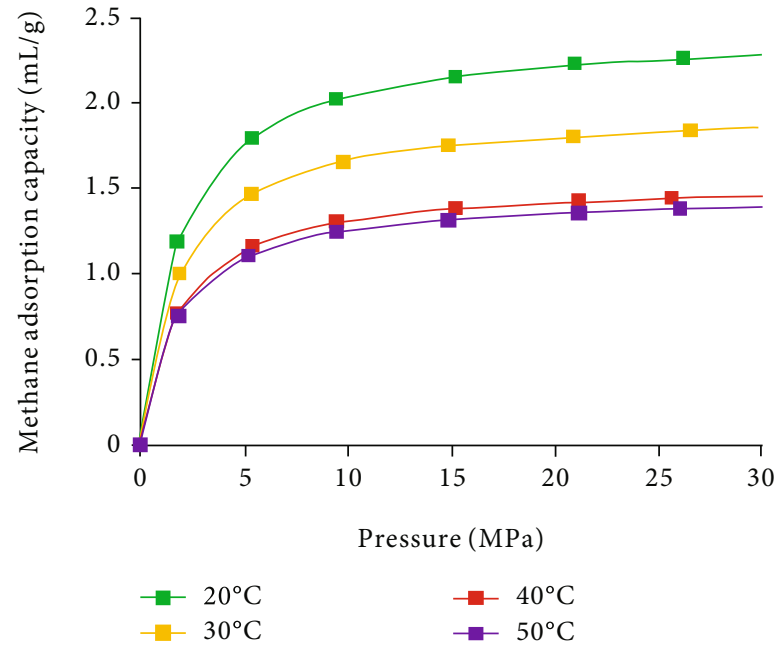

(a)

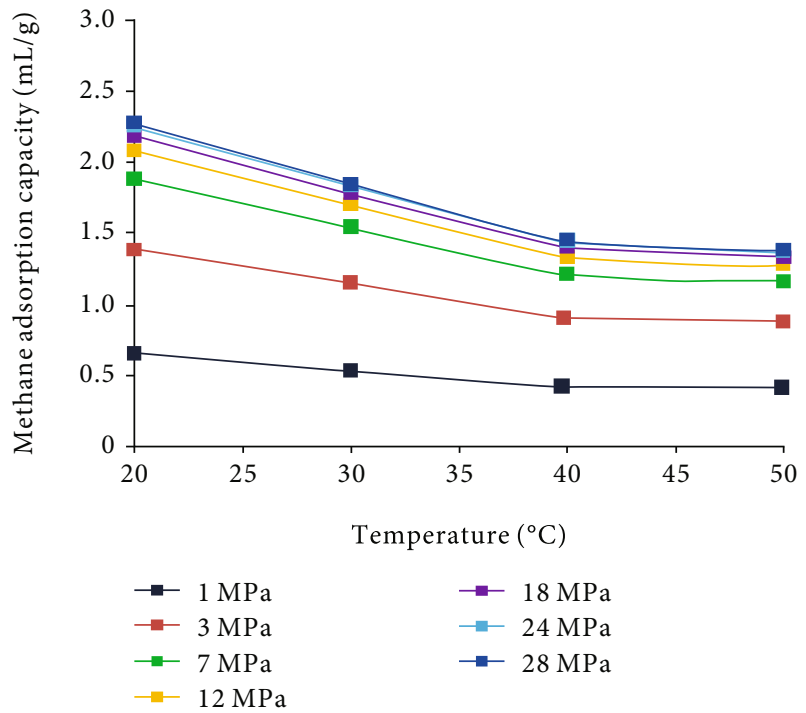

(b)

FIGURE 12: Effect of pressure and temperature on methane adsorption capacity. (a) As the pressure increases, the methane adsorption capacity gradually increases, and the increasing trend decreases after $5 \mathrm{MPa}$. (b) As the temperature increases, the methane adsorption capacity gradually decreases, and after $40^{\circ} \mathrm{C}$, the increase rate decreases.

fit between the layers, which causes the crystal layer expansion to follow the vertical plane. At the same time, a small part of $\mathrm{Si}^{4+}$ in the tetrahedral layer of the crystal lattice is replaced by $\mathrm{Al}^{3+}, \mathrm{P}^{5+}$, etc., and the octahedral layer is often replaced by $\mathrm{Mg}^{2+}, \mathrm{Fe}^{3+}, \mathrm{Zn}^{2+}, \mathrm{Li}^{+}$, etc. This increases the distance between the crystal layers and allows more water molecules to enter the crystal layers, causing the mineral to expand. The crystal structure of illite is similar to that of smectite. The difference is that the hydration ability of illite is small, making it difficult for water molecules to enter between the layers and for illite to expand. The presence of hydrogen bonds between the kaolinite crystal layers makes the cells tightly connected, thus, limiting the entrance of water molecules. The results of a quantitative study on the water absorption capacity of the mineral component of the shale of the Xujiahe Formation in the Sichuan Basin show that the water absorption capacity is highest in smectite, followed by illite, chlorite, kaolinite, and kerogen. At the same time, according to the water content at various levels of humidity, the corresponding water content can be calculated, and then, by combing the porosity, the water saturation can be calculated (Figure 10).

After the clay minerals absorb water, the surface adsorption sites are occupied by water molecules, reducing the adsorption capacity of the clay minerals [37]. At the same time, because clay minerals have the characteristics of water swelling, the increase in the interlayer spacing during expansion reduces the pore volume and connectivity, reducing the space for free gas of clay minerals. The relationship between the adsorption capacity and water saturation of shale in different layers in the Sichuan Basin shows that the adsorption capacity of lacustrine shale, such as the Xujiahe Formation and the Ziliujing Formation, has decreased the most significantly due to the abundance of clay minerals (Figure 11).
5.3. Temperature and Pressure. In addition to the surface properties of shale, the adsorption capacity of shale is affected by temperature and pressure [38, 39]. At a constant temperature, the adsorption gas content of the same sample increases with an increase in pressure, which also proves that there is a positive correlation between pressure and adsorption capacity. However, it can be seen from the shape of the adsorption curve that the increase in pressure has a limited effect on the content of adsorbed gas (Figure 12). In the beginning stage (pressure increases from 0 to $5 \mathrm{MPa}$ ), the increase in pressure has the most obvious effect on the content of adsorbed gas, and the slope of the curve is larger. After that, the increase in pressure caused the content of adsorbed gas to increase more slowly. After the pressure increased to $10 \mathrm{MPa}$, the influence of pressure on the amount of adsorbed gas in shale was significantly reduced, and the amount of adsorbed gas remained fundamentally unchanged; the control effect of pressure on the content of adsorbed gas gradually disappeared (Figure 12). When the pressure is low, the gas adsorption needs to reach a higher binding energy, and the adsorption gas content increases with the pressure. When the pressure increases continuously, the required binding energy decreases continuously, and the gas adsorption rate decreases accordingly [31]. For the same sample under the same pressure, a decrease in temperature causes a higher adsorption content. Specifically, when the temperature increases from $20^{\circ} \mathrm{C}$ to $40^{\circ} \mathrm{C}$, the slope of the adsorption capacity decline is evident. When the temperature exceeds $40^{\circ} \mathrm{C}$, the amplitude of the decrease gradually lessens (Figure 12). This is because gas adsorption is an exothermic process. As the temperature increases, the exothermic process is suppressed and the amount of adsorbed gas decreases. 


\section{Conclusion}

(1) The five sets of shales had different methane adsorption capacities and the order was Longtan Formation > Qiongzhusi Formation and Longmaxi Formation $>$ Xujiahe Formation and Ziliujing Formation

(2) The methane adsorption capacity was positively correlated with TOC, while negatively correlated with humidity. And in a specific range, it was positively correlated with pressure, while negatively correlated with temperature

(3) The methane adsorption capacity first increased and then decreased as maturity increased. For clay minerals, the methane adsorption capacity of smectite was the highest, followed by illite/smectite, kaolinite, chlorite, and illite. While the brittle minerals such as quartz and feldspar had the weakest adsorption capacity for methane

\section{Data Availability}

The data used to support the findings of this study are available from the corresponding author upon request.

\section{Conflicts of Interest}

The authors declare that there are no conflicts of interest regarding the publication of this paper.

\section{Acknowledgments}

The National Natural Science Foundation of China (41802153 and 41728004) and the Key Project of National Science and Technology (2017ZX05035-002) provided funds for this study. We acknowledge support received from the Southwest Oil \& Gas Field Company and the Jianghan Oilfield Company. We express our appreciation for their approval to publish the data.

\section{References}

[1] W. L. Auping, E. Pruyt, S. Jong, and J. H. Kwakkel, “The geopolitical impact of the shale revolution: exploring consequences on energy prices and rentier states," Energy Policy, vol. 98, pp. 390-399, 2016.

[2] K. Zhang, C. Jia, Y. Song et al., "Analysis of lower Cambrian shale gas composition, source and accumulation pattern in different tectonic backgrounds: a case study of Weiyuan block in the upper Yangtze region and Xiuwu Basin in the lower Yangtze region," Fuel, vol. 263, 2020.

[3] T. Jiang, Z. Jin, G. Liu et al., "Source analysis of siliceous minerals and uranium in early Cambrian shales, South China: significance for shale gas exploration," Marine and Petroleum Geology, vol. 102, pp. 101-108, 2018.

[4] X. Tang, Z. Jiang, S. Jiang et al., "Characteristics, capability, and origin of shale gas desorption of the Longmaxi Formation in the southeastern Sichuan Basin, China," Scientific Reports, vol. 9, no. 1, pp. 1-12, 2019.
[5] Y. Ma, X. Cai, and P. Zhao, "China's shale gas exploration and development: understanding and practice," Petroleum Exploration and Development, vol. 45, no. 4, pp. 589-603, 2018.

[6] Y. Pang, M. Y. Soliman, H. Deng, and X. Xie, "Experimental and analytical investigation of adsorption effects on shale gas transport in organic nanopores," Fuel, vol. 199, pp. 272-288, 2017.

[7] Y. Shuai, S. Yu-Ming, Z. Lian-Hui, X. Run-Cheng, and W. Lei, "Research of shale gas isothemal adsorption quantity and equal amount adsorption heat," Science Technology and Engineering, vol. 13, no. 29, pp. 8572-8578, 2013.

[8] B. Zhang, B. Shan, Y. Zhao, and L. Zhang, "Review of formation and gas characteristics in shale gas reservoirs," Energies, vol. 13, no. 20, p. 5427, 2020.

[9] X. Tang, Z. Jiang, S. Jiang, L. Cheng, and Y. Zhang, "Characteristics and origin of in-situ gas desorption of the Cambrian Shuijingtuo Formation shale gas reservoir in the Sichuan Basin, China," Fuel, vol. 187, pp. 285-295, 2017.

[10] Z. Pan and L. D. Connell, "Reservoir simulation of free and adsorbed gas production from shale," Journal of Natural Gas Science \& Engineering, vol. 22, pp. 359-370, 2015.

[11] Y. Liu, J. Zhang, and X. Tang, "Predicting the proportion of free and adsorbed gas by isotopic geochemical data: a case study from lower Permian shale in the southern North China basin (SNCB)," International Journal of Coal Geology, vol. 156, pp. 25-35, 2016.

[12] P. Li, Z. Jiang, M. Zheng, H. Bi, and L. Chen, "Estimation of shale gas adsorption capacity of the Longmaxi Formation in the upper Yangtze Platform, China," Journal of Natural Gas Science and Engineering, vol. 34, pp. 1034-1043, 2016.

[13] W. Ji, F. Hao, H.-M. Schulz, Y. Song, and J. Tian, "The architecture of organic matter and its pores in highly mature gas shales of the lower Silurian Longmaxi Formation in the upper Yangtze platform, South China," AAPG Bulletin, vol. 102, no. 12, pp. 2909-2942, 2019.

[14] K. Xi, Y. Cao, K. Liu et al., "Authigenic minerals related to wettability and their impacts on oil accumulation in tight sandstone reservoirs: an example from the lower Cretaceous Quantou Formation in the southern Songliao Basin, China," Journal of Asian Earth Sciences, vol. 178, pp. 173-192, 2019.

[15] K. Liu, L. Wang, M. Ostadhassan, J. Zou, B. Bubach, and R. Rezaee, "Nanopore structure comparison between shale oil and shale gas: examples from the Bakken and Longmaxi Formations," Petroleum Science, vol. 16, no. 1, pp. 77-93, 2019.

[16] Y. F. Li, W. Sun, X. W. Liu, D. W. Zhang, Y. C. Wang, and Z. Y. Liu, "Study of the relationship between fractures and highly productive shale gas zones, Longmaxi Formation, Jiaoshiba area in eastern Sichuan," Petroleum Science, vol. 15, no. 3, pp. 498-509, 2018.

[17] U. Raut, M. Famá, B. D. Teolis, and R. A. Baragiola, "Characterization of porosity in vapor-deposited amorphous solid water from methane adsorption," Journal of Chemical Physics, vol. 127, no. 20, 2007.

[18] D. J. K. Ross and R. M. Bustin, "Impact of mass balance calculations on adsorption capacities in microporous shale gas reservoirs," Fuel, vol. 86, no. 17-18, pp. 2696-2706, 2007.

[19] J. K. Hill and P. A. Wheeler, "Organic carbon and nitrogen in the northern California current system: comparison of offshore, river plume, and coastally upwelled waters," Progress in Oceanography, vol. 53, no. 2-4, pp. 369-387, 2002. 
[20] A. L. Cheng and W. L. Huang, "Selective adsorption of hydrocarbon gases on clays and organic matter," Organic Geochemistry, vol. 35, no. 4, pp. 413-423, 2004.

[21] O. P. O. Cancino, D. P. Mancilla, M. Pozo, E. Pérez, and D. Bessieres, "Effect of organic matter and thermal maturity on methane adsorption capacity on shales from the middle Magdalena Valley Basin in Colombia," Energy \& Fuels, vol. 31, no. 11, pp. 11698-11709, 2017.

[22] S. Chen, Y. Zhu, H. Wang, H. Liu, W. Wei, and J. Fang, "Shale gas reservoir characterisation: a typical case in the southern Sichuan Basin of China," Energy, vol. 36, no. 11, pp. 66096616, 2011.

[23] J. Tan, P. Weniger, B. Krooss et al., "Shale gas potential of the major marine shale formations in the upper Yangtze platform, South China, part II: methane sorption capacity," Fuel, vol. 129, pp. 204-218, 2014.

[24] Y. Zhang, Z. He, S. Jiang et al., "Factors affecting shale gas accumulation in overmature shales case study from lower Cambrian shale in western Sichuan Basin, South China," Energy \& Fuels, vol. 32, no. 3, pp. 3003-3012, 2018.

[25] J.-n. Peng, D.-y. Wang, G.-x. Liu, M. Zhang, and F.-1. Li, "Carbon isotopic composition and genetic types of natural gas in the Sichuan Basin, China," Acta Geochimica, vol. 36, no. 1, pp. 102-111, 2017.

[26] J. P. Zhang, S. H. Tang, and D. X. Guo, "Shale gas favorable area prediction of the Qiongzhusi Formation and Longmaxi Formation of lower Palaeozoic in Sichuan Basin, China," Geological Bulletin of China, vol. 30, no. 2, pp. 357-363, 2011.

[27] G. R. Chalmers, R. M. Bustin, and I. M. Power, "Characterization of gas shale pore systems by porosimetry, pycnometry, surface area, and field emission scanning electron microscopy/transmission electron microscopy image analyses: examples from the Barnett, Woodford, Haynesville, Marcellus, and Doig units," AAPG Bulletin, vol. 96, no. 6, pp. 10991119, 2012.

[28] T. Zhang, G. S. Ellis, S. C. Ruppel, K. Milliken, and R. Yang, "Effect of organic-matter type and thermal maturity on methane adsorption in shale-gas systems," Organic Geochemistry, vol. 47, no. 6, pp. 120-131, 2012.

[29] A. M. M. Bustin and R. M. Bustin, "Importance of rock properties on the producibility of gas shales," International Journal of Coal Geology, vol. 103, pp. 132-147, 2012.

[30] M. Yamamoto and Y. Watanabe, "Kerogen and biomarker compositions of uranium-rich coaly shales from Miocene sequence at Kanamaru, Japan," Bulletin. Geological Survey of Japan, vol. 61, pp. 325-336, 2005.

[31] Y. Pang, Y. Tian, M. Y. Soliman, and Y. Shen, "Experimental measurement and analytical estimation of methane absorption in shale kerogen," Fuel, vol. 240, pp. 192-205, 2019.

[32] H. Hu, T. Zhang, J. D. Wiggins-Camacho, G. S. Ellis, M. D. Lewan, and X. Zhang, "Experimental investigation of changes in methane adsorption of bitumen-free Woodford shale with thermal maturation induced by hydrous pyrolysis," Marine \& Petroleum Geology, vol. 59, pp. 114-128, 2015.

[33] Y. M. Wang, D. Z. Dong, H. Yang et al., "Quantitative characterization of reservoir space in the lower Silurian Longmaxi Shale, southern Sichuan, China," Science China Earth Sciences, vol. 57, no. 2, pp. 313-322, 2014.

[34] D. J. K. Ross and R. M. Bustin, "The importance of shale composition and pore structure upon gas storage potential of shale gas reservoirs," Marine \& Petroleum Geology, vol. 26, no. 6, pp. 916-927, 2009.

[35] L. Ji, J. Qiu, Y. Xia, and T. Zhang, "Micro-pore characteristics and methane adsorption properties of common clay minerals by electron microscope scanning," Acta Petrologica Sinica, vol. 33, no. 2, pp. 249-256, 2012.

[36] C. J. van Oss, "The hydrophilicity and hydrophobicity of clay minerals," Clays and Clay Minerals, vol. 43, no. 4, pp. 474477, 1995.

[37] J. Li, X. Li, X. Wang et al., "Water distribution characteristic and effect on methane adsorption capacity in shale clay," International Journal of Coal Geology, vol. 159, pp. 135-154, 2016.

[38] V. Sharma and A. Sircar, "Multi-technique characterization of shale reservoir quality parameters," Journal of Natural Gas Science and Engineering, vol. 75, 2019.

[39] A. Hildenbrand, B. M. Krooss, A. Busch, and R. Gaschnitz, "Evolution of methane sorption capacity of coal seams as a function of burial history - a case study from the Campine Basin, NE Belgium," International Journal of Coal Geology, vol. 66, no. 3, pp. 179-203, 2006. 